\title{
The diversity of geomorphological features of peatland basins in Central Poland and its paleoecological significance - a review
}

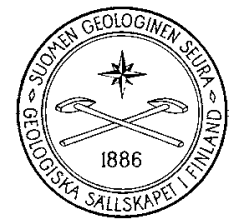

VERTAISARVIOITU KOLLEGIALT GRANSKAD PEER-REVIEWED
www.tsv.ti/tunnus

\author{
JaCEK Forysiak \\ Department of Geomorphology and Paleogeography, Faculty of Geographical Sciences, \\ University of Łódź, Narutowicza 88, 90-139 Łódź, Poland
}

Keywords: peatland, biogenic deposits, geomorphological features, Late Vistulian, Holocene, Central Poland

author e-mail: jacek.forysiak@geo.uni.lodz.pl

Editorial handling: Pertti Sarala (pertti.sarala@gtk.fi)

\section{Introduction}

Central Poland is in a peatland zone in which fens dominate (Żurek, 1987; Succow \& Joosten, 2001), whereas raised mires may also be encountered. These peatlands are variable in terms of water supply, as well as their surface area and the volume of biogenic sediments (Źurek, 1984, 1987). The area of Central Poland (the Łódź Region), where the field 
studies documented here were conducted, is outside the reach of the ice sheet of the last glaciation (Fig. 1). This area was covered by the ice sheet during the Warta Stadial of the Saalian Glaciation (MIS 6) and earlier glaciations (Marks et al., 2018). The surface geological structure is predominantly characterised by glacigenic sediments, and considerable amounts of the surface are covered with fluvial, slope, and aeolian deposits of the Vistulian. At that time, intensive periglacial processes took place under conditions in which tundra vegetation dominated, whereas during warmer phases the plant cover and forest assemblages characteristic of temperate zone developed (Klatkowa, 1996). In the Early Vistulian and Plenivistulian, there were many lakes and peatlands in Central Poland (Roman, 2016). However, intensive land-forming processes led to their extensive transformation, often entailing the destruction of such forms and damage to the deposited biogenic sediments. Intensive morphological processes were halted at the end of the Plenivistulian. In the Late Vistulian, there were still aeolian, thermokarst and fluvial processes active, which were associated with the river system adapting to new environmental conditions. Such transformations of the initial glacial landform led to the significant geomorphological variety in the area and the differentiation of the surface geology structure. This made it possible for numerous depressions to form, in which wetlands presently visible in the landscape of the area, could develop. The changing climatic and hydrological conditions of the Late Vistulian and Holocene allowed the peatlands and lakes to develop and function. With time, the lakes went through a stage of terrestrialisation and changed into peatlands.

This article is based on studies by the author and a team of specialists in paleoecology, a significant portion of whose results have already been published. The article aims to indicate how significant the geomorphological and geological conditions of basins were for the creation and functioning of peatlands in them, and for the course of biogenic sediment deposition. The geomorphological features of the basins of peatlands and lakes are important to the continuity, deposition, and behaviour of biogenic sediments, along with the hydrological and climatic conditions, which are vital for the functioning of peatlands and lakes (Charman, 2002; Rydin \& Jeglum, 2006). This paper will not discuss the study methodology and will not present results, because these have all been described in detail in other papers (Forysiak, 2012, 2015; Forysiak et al., 2010, 2011, 2012). A number of examples will be shown to represent the units developed in different forms in glacial uplands within the reach of aeolian forms or in valleys.

\section{Study sites}

The study area is located in the Polish lowlands. There are large peatlands within the extensive depressions known as the Łowicz-Błonie Basin, the Szczerców Basin, and the Koło Basin. The morainic uplands, which were transformed by periglacial conditions, mainly feature small peatlands. Geological, geomorphological, and paleoecological surveys carried out in Central Poland (the Eódź Region) focused on the surroundings and substratum of the peatlands, as well as on the biogenic sediments deposited in their basins. The studies covered over 30 peatlands (Forysiak, 2012), but this paper presents only a number of examples (Fig. 1) which represent units that developed in multiple formations in areas of glacial uplands and within the reach of aeolian forms or in valleys (i.e. of different origins). In the examined part of Central Poland, peatlands are predominantly located in river valleys. Of the fifteen shown in Fig. 1, seven are located in active river valleys (see Fig. 1, sites 1-7). Another three peatlands formed in river valleys, which were excluded from open river systems during 


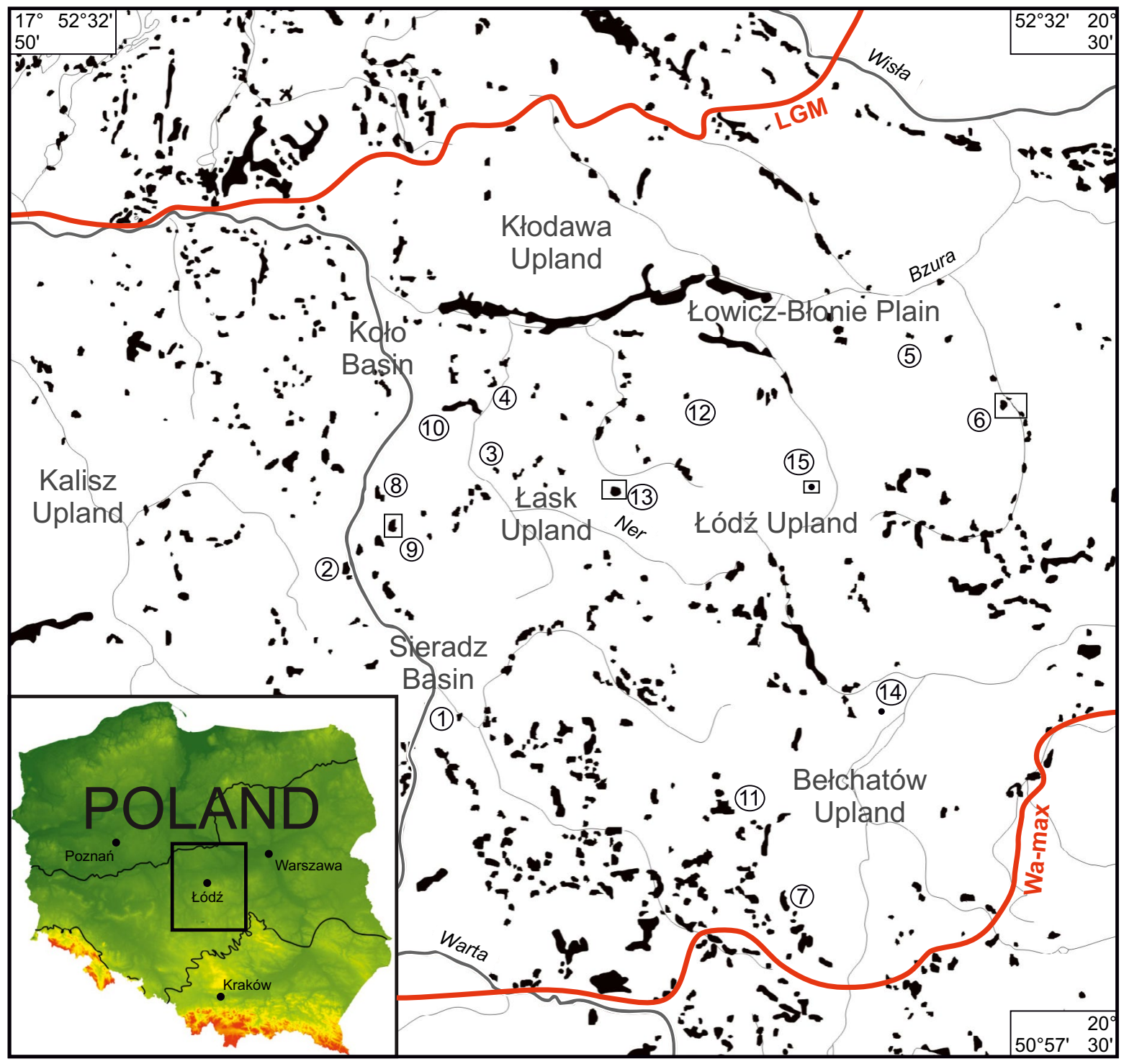

Figure 1. Study area. Location of wetlands in Central Poland. Peatland described in text: 1 - Korzeń, 2 - Bartochów, 3 - Mianów, 4 - Ner-Zawada, 5 - Polesie, 6 - Kopanicha, 7 - Bęczkowice; 8 - Józefka, 9 - Ługi, 10 - Wilczków, 11 - Napoleonów; 12 - Witów-Silne Błoto, 13 - Rąbień, 14 - Czarny Ług, 15 - Żabieniec. Rectangles correspond to the ranges of geomorphological maps on Fig. 2. The red lines indicate the maximum range of the ice sheet during Vistulian and Warta Stadial.

the Plenivistulian (Fig. 1, sites 8-10). One of the example sites is located in a valley formed by proglacial outflow. The next group are peatlands associated with aeolian forms (Fig. 1, site 12-14), which are found both in valleys and in uplands. In the study area, several peatlands function on morainic uplands, but here only one is shown (Fig. 1, site 15) 


\section{Review of geological, geomorphological and paleoecological setting}

Geological and geomorphological fieldwork were carried out in the study area during 2005-2014. Many manual and mechanical drillings were carried out in peatlands and their surroundings, and detailed data has been published by Forysiak (2012). Recognition of the lithology and thickness of biogenic deposits allowed a number of sites to be selected for collection of cores to analyse. These deposits were sampled using an Instorf sampler or piston corer. During the research cycle, palynological, plant macrofossil and paleozoological analyses and radiocarbon dating were carried out (Forysiak, 2012, 2015; Forysiak et al., 2010, 2011, 2012). Because the tested sediment cores were from 2 to $16 \mathrm{~m}$ deep, samples for the aforementioned analyses were taken at different intervals: from 2 to $10 \mathrm{~cm}$. All the stratigraphical conclusions expressed in this article are the result of this palynological research and dating of sediments.

The most numerous group among the studied peatlands is of those located in river valleys (Fig. 1). They often exist in an environment of active fluvial processes, where the peatlands function in floodplain basins or oxbow lakes and where they occupy extensive parts of valley bottoms or terrace depressions of thermokarst origin (Forysiak, 2015). The thickness of peats and accompanying lacustrine sediments in the studied peatlands of the Łódź region varies from $1.5 \mathrm{~m}$ to $5.0 \mathrm{~m}$. An interesting example is the Kopanicha Peatland in the Rawka River valley (Figs. 1, 2a) in a flood basin which became covered with peat in the middle of the Holocene (Forysiak et al., 2011; Pawłowski et al., 2012). Paleobotanical research was carried out on sediments of a core having a thickness of $3.8 \mathrm{~m}$, which is the largest thickness found in
Kopanicha (Forysiak, 2012). A large proportion of the peatlands formed in valleys, which were disconnected from the river system, and this includes parts of the bottoms of ice-marginal valleys, cut-off fragments of river valleys, and transformed glacigenic or thermokarst basins (Forysiak, 2015). The Ługi mire is an interesting example of a wetland having formed in an abandoned valley floor (Figs. 1, 2d). It is situated in a part of the Warta river valley that was excluded from the river system in the erosional phase at the end of Plenivistulian (Klatkowa \& Załoba, 1991; Forysiak, 2012).

Another relatively numerous group is that of peatlands near aeolian formations. The development of the basins of these peatlands is directly associated with the activity of aeolian processes in the Late Vistulian and the Holocene. Many smaller units have also been observed which formed in Holocene deflation depressions (Forysiak, 2012, 2015) connected with human-induced phases of aeolisation (Twardy, 2011). Greater paleogeographical and paleoecological significance may be attributed, however, to the wetlands formed in the Late Vistulian, which underwent transformations during the dune-forming phases (Wasylikowa, 1964; Dylikowa, 1969). The Witów site, which is located at the edge of the Silne Błoto mire, is of great importance (Wasylikowa, 1964). The Rąbień mire is similarly located (Figs. 1, 2c) in a basin cut off by a migrating dune (Kloss, 2005; Forysiak, 2012, 2015). In the deepest part of the peatland basin, $6.2 \mathrm{~m}$ of lacustrine sediments and peat have been documented (Fig. 2), which is the largest thickness in this group of peatlands (Forysiak, 2012). Initially, from the Oldest Dryas, the deposits formed in a lake, which in the Holocene was transformed into a fen with a raised bog at the centre (Kloss, 2005; Słowiński et al., 2016).

Peatlands located on morainic uplands make a much smaller group. They occupy depressions 

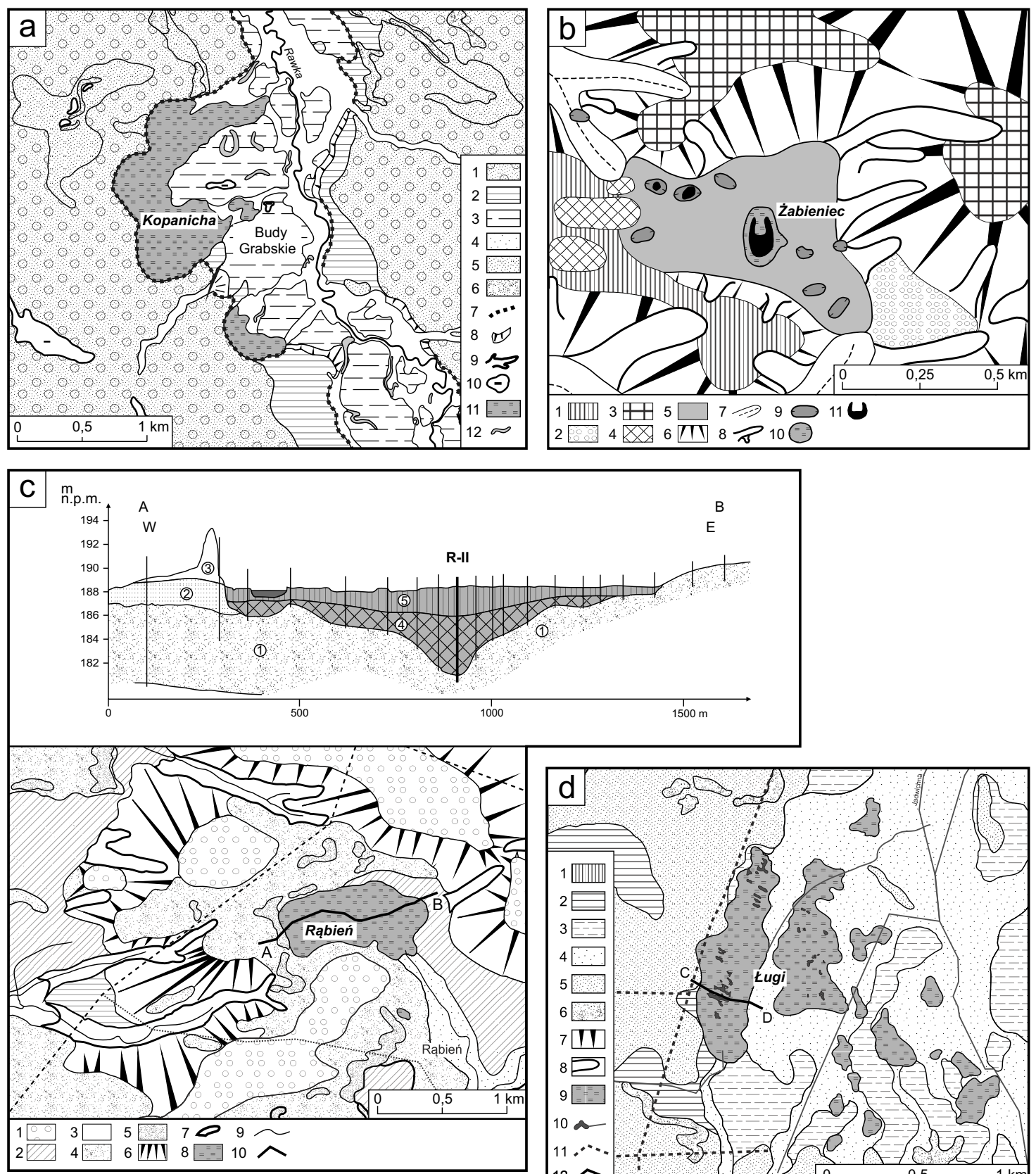
of glacial origin with extensive periglacial transformations which retained a shape that supported the formation of a peatland. The best studied example is the Żabieniec mire (Figs. 1, 2b), where lacustrine sediments of the Late Vistulian and Early Holocene covered by the Late Holocene peats were documented (Lamentowicz et al., 2009; Twardy et al., 2010). This site has the largest thickness of lacustrine peat sediments deposited in the above-mentioned period in Central Poland, at $16.3 \mathrm{~m}$, and the collected sediment samples are still being analysed by paleobotanists and paleozoologists.

Figure 2. Geological and geomorphological illustrations of selected peatland.

a) Kopanicha Peatland. Geomorphological map:

1 - fluvioglacial plain; 2 - high terrace; 3 - low terrace;

4 - valley bottom; 5 - aeolian sand sheets; 6 - dunes;

7 - erosional edges; 8 - slopes; 9 - denudational valleys;

10 - closed depressions; 11 - peatland; 12 - oxbow lakes; (after Forysiak 2012, changed).

b) Żabieniec Peatland. Geomorphological map: 1 - flat morainic plain; 2 - fluvioglacial plain; 3 - fluvioglacial hillocks; 4 - morainic hillocks; 5 - kettle hole; 6 - slopes;

7 - major denudational valleys; 8 - dells and small denudational valleys; 9 - closed depressions;

10 - peatland ; 11 - waters; (after Twardy et al., 2010, changed).

c) Rąbień Peatland. Geomorphological map:

1 - fluvioglacial hillocks; 2 - fluvial-periglacial plains;

3 - valley bottoms; 4 - aeolian sand sheets; 5 - dunes;

6 - slopes; 7 - denudational valleys; 8 - peatland;

9 - streams; 10 - line of geological cross-section.

Geological cross-section: Plenivistulian: 1 - vari-grained sands with an admixture of silts and gravels; Late Vistulian/Holocene: 2 - aeolian sands, 3 - aeolian sands in dunes, 4 - gyttja, 5 - peat; R-II - location of studied core; (after Forysiak, 2012, changed).

d) Ługi Peatland. Geomorphological sketch: 1 - morainic plain; 2 - high terrace; 3 - elevated parts of valley bottom; 4 - wet parts of valley bottom; 5 - aeolian sand sheets;

6 - dunes; 7 - slopes; 8 - denudational valleys;

9 - peatland; 10 - post-exploitation basins and streams;

11 - roads; 12 - line of geological cross-section.

Geological cross-section. Upper Plenivistulian: 1 - vari-

grained sands, fluvial; Late Vistulian: 2 - sands with inserts of biogenic deposits, 3 - detrital-calcareous gyttja,

4 - detrital gyttja, 5 - sedge-moss peat; Holocene:

6 - reed peat; 7 - aeolian sand, 8 - tall-sedge peat with

muck at the top, 9 - soil accumulation horizon;

Ł-1 - location of studied core. (after Forysiak, 2012,

changed).

\section{Interpretation and discussion}

The significance of the geomorphological and geological conditions of peatland basins for the creation of wetlands in the course of sediment accumulation is rarely assessed in the literature. Geological and geomorphological features are mentioned as important aspects of the functioning of peatlands (Succow \& Joosten, 2001; Charman, 2002; Rydin \& Jeglum, 2006), but these papers do not specify how those features are reflected in the lithology of deposited biogenic sediments, nor in the continuity and quality of the record of paleoenvironmental changes. One example of the issue being dealt with is a work concerned with eastern Poland, which shows the relationship of geomorphological features and hydrological conditions, and their importance for peatforming processes (Żurek, 1990).

The diversified geomorphological features of the basins of peatlands, the varied geological structure of their substratum and the character of the infilling with biogenic sediments all determine how useful the deposits accumulated in peatlands will be for paleoecological and stratigraphic analyses. As is shown by the presented examples from Central Poland, the most favourable conditions for the development of full sequence of biogenic sediments from the end of Plenivistulian to the present are found in relatively deep postglacial depressions in uplands. Żabieniec is one such site, where the dynamics of the morphological processes and the variability of the hydrological conditions in the Late Vistulian and the Holocene were limited and did not disturb the functioning of the lake and mire (Lamentowicz et al., 2009; Twardy et al., 2010). The core contains a record of the transition from the periglacial conditions of Plenivistulian to the Late Glacial conditions (Fig. 3). Such a scenario has been recorded in few lacustrine or peatland sites in the European Lowland (Kolstrup, 1980; Brauer et al., 2001; 


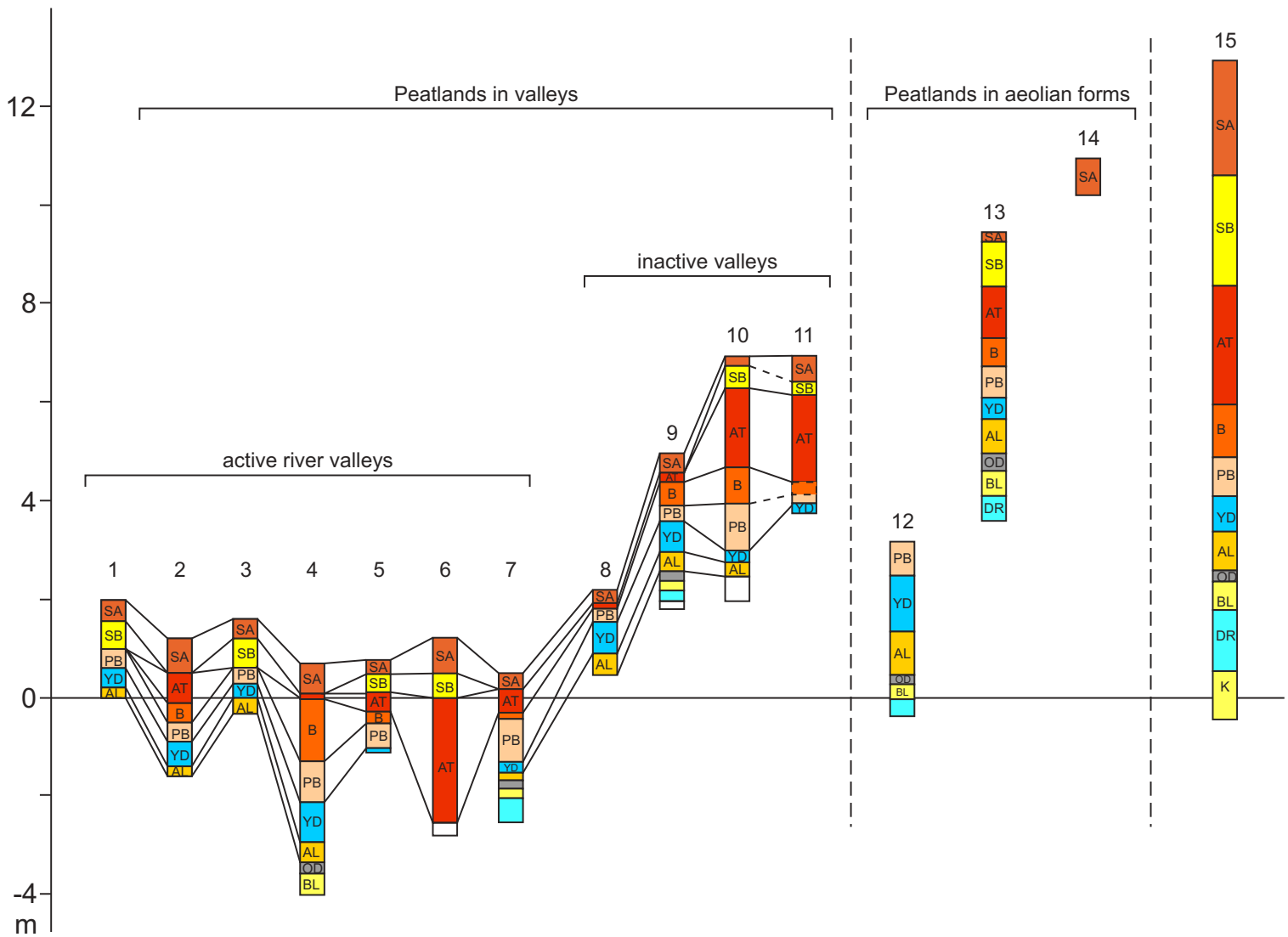

Figure 3. Position and age of biogenic deposits of examined peatlands on the basis of paleobotanical analyses of the cores. The bar height corresponds to the thickness of organic deposits. The zero line refers to the level of water in the river bed draining the peatland or its vicinity. Peatlands in valleys: 1 - Korzeń, 2 - Bartochów, 3 - Mianów, 4 - Ner-Zawada, 5 - Polesie, 6 - Kopanicha, 7 - Bęczkowice; 8 - Józefka, 9 - Ługi, 10 - Wilczków, 11 - Napoleonów; peatlands in aeolian forms: 12 - Witów-Silne Błoto, 13 - Rąbień, 14 - Czarny Ług; peatland in morainic upland: 15 - Żabieniec. Stratigraphy - Mangerud chronozones (after Walanus \& Nalepka, 2010): SA - Subatlantic, SB - Subboreal, A - Atlantic, B - Boreal, PB - Preboreal, YD - Younger Dryas, AL - Allerød, OD - Older Dryas, BL - Bølling, DR - Oldest Dryas and K - Kamion (after Manikowska, 1991).

de Klerk, 2008; Wacnik, 2009; Kołaczek et al., 2015). The lake continued to function until the middle of the Subboreal phase, when a low fen developed and in time became transformed into a raised bog. Owing to a number of paleoecological analyses of its sediments, the Żabieniec mire became an important profile for the area of Poland (Lamentowicz et al., 2009; Płóciennik et al., 2011; Pawłowski et al., 2012). In Central Poland, a few similarly located peatlands have been studied, but none of them in detail in terms of paleoecology. It can be concluded that if a peatland is located in a deep, glacigenic depression of a sufficiently small direct catchment, it is possible for a continuous profile of biogenic sediments to be created and preserved.

The large number and geomorphological diversity of the peatlands located in valleys presents potentially favourable conditions for geological and paleogeographical studies. Nevertheless, the peatlands in the valleys of Central Poland have been subjected to heavy 
human impact in the last 200 years, which has mainly involved drainage for farming, the establishment of meadows or peat exploitation. Therefore, only few places remain with intact biogenic sediment profiles. Peatlands and lakes began to form in valleys as early as the Late Glacial and were often present in the Holocene (Fig. 3). The changes in the groundwater level in valleys, the intensity of water supply (and sometimes the influence of fluvial processes) caused disruption to the accumulation of biogenic sediments (Starkel et al., 2013). Of the studied peatlands, none allowed us to document a continuous deposition of sediments from the Late Vistulian to the Late Holocene, and the missing part was often the Late Glacial, the Early Holocene or the older part of Late Holocene (Fig.3). Of more use for paleoecological reconstructions are sediments deposited in peatlands located in inactive valleys, where the functioning of the peatland is dependent on the level of groundwater. However, such sites are void of intense fluvial or slope processes, in contrast to those located in active river valleys. In valleys, where fluvial processes have ceased or are weakly active, pools of various sizes can be found. They were formed because of the lowering of the surface by thermokarst processes in the older part of the Late Glacial, when there was a melting of masses of ground ice buried in mineral sediments accumulated in the Plenivistulian (Goździk \& Konecka-Betley, 1992). Peatlands developed in such depressions and, after further lowering, were permanently flooded with water, which formed lakes, which then, in the Holocene transformed into peatlands (Goździk \& Konecka-Betley, 1992; Forysiak et al., 2010; Forysiak, 2012). Despite of a good geological survey of the valley peatlands in Central Poland, there is still a shortage of sites with detailed paleoecological record. Cores from several peatlands in valleys were subjected to palynological analysis and dated (Fig. 3).

Peatlands near aeolian forms are particularly sensitive to changes in humidity and they underwent frequent modifications during phases of aeolian activity (Wasylikowa, 1964; KubiakMartens, 1996; Goździk, 2007; Margielewski et al., 2015). The studied sites in Central Poland indicate that relatively large basins near the dune complexes and effectively supplied by groundwaters in the Late Glacial functioned as lakes or peatlands with continuous accumulation of biogenic sediments. It often continued in the Holocene (Fig. 3), a good example of this being the Witów site (Wasylikowa, 1964) or Rąbień (Balwierz, 2005; Forysiak et al., 2012, Słowiński et al., 2016). The group of peatlands connected with aeolian forms also contains smaller objects developed in deflation depressions that occurred as a result of an increase in aeolian activity in response to the defrosting in the Late Holocene (Twardy, 2011). This kind of site is suitable for reconstruction of the environmental conditions in the period of agricultural activity.

The presented conclusions apply to peatlands formed in areas outside the reach of the last glaciation, where geomorphological formations and the surface geological structure were shaped in the Vistulian by mainly periglacial, fluvial, slope, and aeolian processes. The part of the territory of Poland north of the LGM line is much richer in peatlands (Źurek, 1984, 1987; Succow $\&$ Joosten, 2001) but the shaping of their geological subsurface progressed in a different formation, and a comparison of these two areas would require significantly more comprehensive documentation.

\section{Conclusions}

The diversity of the origin of peatland basins in Central Poland allowed peatlands to be distinguished by location (in valleys or upland mires) and by the processes forming their basins (e.g., glacigenic, aeolian, fluvial or thermokarst processes). Peats prevail in the structure of the sediments in the analysed basins of peatlands; the most predominant are fens, whereas the amount of 
raised bogs is low. In parts of the analysed objects there are lacustrine sediments, which usually form the bottom section of the profiles of the biogenic sediments, and were usually accumulated in the Late Vistulian. Some of the analysed sequences contain lacustrine sediments of the Holocene age, which is evidence of a lake being present in that time period also outside the floors of river valleys. The development of upland basins, as well as wide basins of aeolian origin, is endogenous; it begins with the lake stage and subsequently changes into fens, a transitional peatland and raised bogs. In such sites, complete profiles of the sediments of Late Glacial are often documented with a full Holocene sequence. Accumulation basins in river valleys do not provide constant sediment growth as they are dependent on the variable dynamics of fluvial processes, which means that the registered growth of biogenic sediments is not synchronous

\section{References}

Balwierz, Z., 2005. The history of vegetation of the Rąbień Mire region. Monographiae Botanicae 94, 135-144.

Brauer, A., Litt, T., Negendank, J.F.W. \& Zolitschka, B., 2001. Lateglacial varve chronology and biostratigraphy of lakes Holzmaar and Meerfelder Maar, Germany. Boreas 30, 83-88. https://doi.org/10.1111/j.1502-3885.2001.tb00991.x

Charman, D., 2002. Peatlands and Environmental Change. J. Wiley\&Sons, Chichester, $301 \mathrm{p}$.

Dylikowa, A., 1969. Le probleme des dunes interieurs en Pologne a la lumiere des etudes de structure. Biuletyn Peryglacjalny 20, 45-80. (in French)

Forysiak, J., 2012. Zapis zmian środowiska przyrodniczego późnego vistulianu i holocenu w osadach torfowisk regionu łódzkiego. Acta Geographica Lodziensia 99, 164 p. (in Polish)

Forysiak J., 2015. Geomorphological diversity of peatland basins in the Łódź region and its significance for the accumulation of biogenic sediments. Bulletin of Geography. Physical Geography Series 8, 59-70. https://doi.org/10.1515/bgeo-2015-0005

Forysiak, J., Obremska, M., Pawłowski, D. \& Kittel, P., 2010. Late Vistulian and Holocene changes in the Ner River valley in light of geological and palaeocological data from the Ner-Zawada peatland. Geologija 52:1-4, 25-33. https://doi.org/10.2478/v10056-010-0002-4

Forysiak, J., Obremska, M. \& Twardy, J., 2011. Records on anthropogenic environmental changes in small river in all valley peatlands of the region. Peatlands that are fed by groundwater and which are located in inactive valleys can also vary in intensity of growth of their biogenic sediments. The sediments of valley peatlands are not suitable objects for stratigraphic analyses, but they are suitable for reconstructions of short fluvial activity events that occurred in valley floors.

\section{Acknowledgements}

The author thanks Dr Rimanté Guobyté and the anonymous reviewer and editor for their valuable comments, which helped significantly to improve the manuscript. Investigations are funded by the National Science Centre in Poland from the funds conferred for research projects (2 PO4E 022 28; NN306 276735; UMO-2016/21/b/ST10/02451).

valleys in the vicinity of Łowicz (Central Poland): their significance for the reconstructions of Late Holocene settlement tendencies. Bulletin of Geography. Physical Geography Series 4, 7-20. https://doi.org/10.2478/bgeo-2011-0001

Forysiak, J., Borówka, R.K., Kloss, M., Obremska, M., Okupny, D. \& Żurek, S., 2012. Geological and geomorphological features of the Rąbień peatland and preliminary results of investigations of biogenic sediments. Acta Geographica Lodziensia 100, 65-76.

Goździk, J., 2007. The Vistulian aeolian succession in central Poland. Sedimentary Geology, 193, 211-220. https://doi.org/10.1016/j.sedgeo.2005.11.026

Goździk, J. \& Konecka-Betley, K., 1992. Późnovistuliańskie utwory węglanowe w zagłębieniach bezodpływowych rejonu kopalni Bełchatów. Geneza i stratygrafia. Roczniki Gleboznawcze 43:3-4, 103-112. (in Polish)

Klatkowa, H., 1996. Symptoms of the permafrost presence in Middle Poland. Landform Analysis 2, 19-35.

Klatkowa, H. \& Załoba, M., 1991. Kształtowanie budowy geologicznej i rzeźby południowego obrzeżenia Basenu Uniejowskiego. In: Stankowski, W. (ed.) Przemiany środowiska geograficznego obszaru Konin-Turek. UAM Press, Poznań, 33-44. (in Polish)

de Klerk, P., 2008. Patterns in vegetation and sedimentation during the Weichselian Late-glacial in north-eastern Germany. Journal of Biogeography 35, 1308-1322. https://doi.org/10.1111/j.1365-2699.2007.01866.x 
Kloss, M., 2005. Identification of subfossil plant communities and paleohydrological changes in a raised mire development. Monographiae Botanicae 94, 81-116.

Kołaczek, P., Gałka, M., Karpińska-Kołaczek, M. \& Lutyńska, M., 2015. Late Pleniglacial and Late Glacial lake-mire transformations in south-eastern Poland reflected in aquatic and wetland vegetation changes. Quaternary International 388, 39-50. https://doi.org/10.1016/j.quaint.2014.04.042

Kolstrup, E., 1980. Climate and stratigraphy in north-western Europe between $30000 \mathrm{BP}$ and $13000 \mathrm{BP}$ with special reference to the Netherlands. Mededelingen Rijks Geologische Dienst 32, 181-253.

Kubiak-Martens, L., 1996. Evidence for possible use of plant foods in Palaeolithic and Mesolithic diet from the site of Całowanie in the central part of the Polish Plain. Vegetation History and Archaeobotany 5, 33-38. https://doi.org/10.1007/BF00189433

Lamentowicz, M., Balwierz, Z., Forysiak, J., Płóciennik, M., Kittel, P., Kloss, M., Twardy, J., Żurek, S. \& Pawlyta, J., 2009. Multiproxy study of anthropogenic and climatic changes in the last two millennia from a small mire in central Poland. Hydrobiologia 631, 213-230. https://doi.org/10.1007/s10750-009-9812-y

Margielewski, W., Krąpiec, M., Jankowski, L., Urban, J. \& Zernitskaya, V., 2015. Impact of aeolian processes on peat accumulation: Late Glacial-Holocene history of the Hamernia peat bog (Roztocze region, south-eastern Poland). Quaternary International 386, 212-225. https://doi.org/10.1016/j.quaint.2015.07.016

Marks, L., Karabanov, A., Nitychoruk, J., Bahdasarau, M., Krzywicki, T., Majecka, A., Pochocka-Szwarc, K., Rychel, J., Woronko, B., Zbucki, Ł., Hradunova, A., Hrychanik, M., Mamchyk, S., Rylova, T., Nowacki, Ł. \& Pielach, M., 2018. Revised limit of the Saalian ice sheet in central Europe. Quaternary International 478, 59-74. https://doi.org/10.1016/j.quaint.2016.07.043

Manikowska, B., 1991. Vistulian and Holocene aeolian activity, pedostratigraphy and relief evolution in Central Poland. -Zeitschrift für Geomorphologie, NF 90, 131-141.

Pawłowski, D., Kloss, M., Obremska, M., Szymanowski, M., Żurek, S., 2012. Evolution of small valley mire in central Poland as a result of hydroclimatic oscillations. Geochronometria 39, 133-148. https://doi.org/10.2478/s13386-012-0004-6

Płóciennik, M., Self, A., Birks, H.B.J. \& Brooks, S.J., 2011. Chironomidae (Insecta: Diptera) succession in Żabieniec bog and its palaeolake (Central Poland) through the Late Weichselian and Holocene. Palaeogeography, Palaeoclimatology, Palaeoecology 307, 150-167. https://doi.org/10.1016/j.palaeo.2011.05.010
Roman, M., 2016. Pojezierze eemskie: uwagi o genezie i zaniku jezior polodowcowych centralnej Polski. Acta Geographica Lodziensia 105, 11-25. (in Polish)

Rydin H. \& Jeglum J., 2006. The biology of peatlands. Oxford University Press, $343 \mathrm{p}$.

Słowiński, M., Marcisz, K., Płóciennik, M., Obremska, M., Pawłowski, D., Okupny, D., Słowińska, S., Borówka, R.K., Kittel, P., Forysiak, J., Michczyńska, D.J. \& Lamentowicz, M., 2016. Drought as a stress driver of ecological changes in peatland - A palaeoecological study of peatland development between 3500 BCE and 200 BCE in central Poland. Palaeogeography, Palaeoclimatology, Palaeoecology 461, 272-291. https://doi.org/10.1016/j.palaeo.2016.08.038

Starkel, L., Michczyńska, D.J., Krąpiec, M., Margielewski, W., Nalepka, D. \& Pazdur, A., 2013. Progress in the holocene chrono-climatostratigraphy of Polish territory. Geochronometria 40, 1-21. https://doi.org/10.2478/s13386-012-0024-2

Succow, M. \& Joosten, H., 2001. Landschaftsökologische Moorkunde. E. Schweizerbart'sche Verlagsbuchhandlung, Stuttgart, 622 p. (in German)

Twardy, J., 2011. Influence of man and climate changes on relief and geological structure transformation in central Poland since the Neolithic. Geographia Polonica 84, 163-178. https://doi.org/10.7163/GPol.2011.S1.11

Twardy, J., Żurek, S. \& Forysiak, J., 2010. Torfowisko Żabieniec. Warunki naturalne, rozwój i zapis zmian paleoekologicznych w jego osadach. Bogucki Press, Poznań, 214 p. (in Polish)

Wacnik, A., 2009. Vegetation development in the Lake Miłkowskie area, north-eastern Poland, from the Plenivistulian to the late Holocene. Acta Palaeobotanica 49, 287-335.

Walanus, A. \& Nalepka, D., 2010. Calibration of Mangerud's boundaries. Radiocarbon 52, 1639-1644. https://doi.org/10.1017/S0033822200056368

Wasylikowa, K., 1964. Vegetation and climate of the LateGlacial in Central Poland based on investigations made at Witów near Łęczyca. Biuletyn Peryglacjalny 13, 261-417.

Żurek, S. 1984. Verteilung und Charakter europäischer Moore. Telma 14, 113-125. (in German)

Żurek, S., 1987 - Złoża torfowe Polski na tle stref torfowych Europy. Dokumentacja Geograficzna 4, 84 p. (in Polish)

Żurek, S., 1990. Związek procesów zatorfienia z elementami środowiska przyrodniczego wschodniej Polski. Roczniki Nauk Rolniczych, Seria D 220: 174 p. (in Polish) 